\title{
Media policy in the 21st century: from national interest to cultural stewardship
}

\section{Política de comunicação no século XXT:} do interesse nacional à gestão cultural

\author{
MICHAEL CURTIN* \\ University of California, Department of Film and Media Studies, Santa Barbara-CA, EUA
}

\begin{abstract}
This essay provides a framework for understanding the twenty-first century dynamics of the global media economy. It has four central objectives: (1) explain the fundamental shift in media regulation engendered by neo-liberal globalization; (2) describe the operations of transnational commercial media enterprises and show how their practices and protocols have affected media institutions at the local, national, and regional levels; (3) identify issues that have risen to the forefront of media policy deliberations with respect to cultural expression and creative labor; and (4) elaborate an alternative policy perspective based on the principle of stewardship.
\end{abstract}

Keywords: Políticas de comunicação, regulação da mídia, gestão cultural

\section{RESUMO}

Este ensaio fornece um enquadramento para compreender as dinâmicas do século vinte e um da economia da comunicação global. Ele possui quatro objetivos principais: (1) explicar a mudança fundamental na regulação da mídia provocada pela globalização neoliberal; (2) descrever as operações das empresas transnacionais de mídia comercial e mostrar como suas práticas e protocolos afetaram as instituições de mídia em níveis local, nacional e regional; (3) identificar questões que têm alcançado o primeiro plano das deliberações da política de comunicação, com respeito à expressão cultural e ao trabalho criativo; e (4) elaborar uma perspectiva alternativa de política baseada no princípio de stewardship.

Palavras-chave: Políticas de comunicação, regulação da mídia, stewardship
* Professor of Global Studies and of Film and Media Studies at the University of California. Published, among other books, Playing to the World's Biggest Audience: The Globalization of Chinese Film and TV (University of California Press, 2007). He is co-editor of the International Screen Industries book series for the British Film Institute and co-editor of the Chinese Journal of Communication. E-mail:mcurtin@ filmandmedia.ucsb.edu 
INCE THE 1990S, market liberalization and new technologies have accelerated the transnational flow of media imagery much to the delight of Western conglomerates that have expanded their operations and exports around the globe. This has, of course, raised anxieties in countries that find themselves ever more vulnerable to a flood of foreign films, television shows, and online video. Yet Hollywood is no longer the only major exporter of audiovisual media, having been joined by a host of thriving competitors, including Mumbai, Lagos, Miami, and Sao Paulo (Curtin, 2003, 2011). Commercial enterprises in these cities are now distributing popular fare to regional, diasporic, and even global audiences.

As these transnational media capitals prosper, many national and local governments have expressed concern about the ability of their indigenous cultural institutions to produce screen media content that can sustain the allegiances of resident populations in the face of global competition. Policymakers are furthermore aware that creative labor has come to be perceived as a valuable component of a healthy national economy, stimulating innovation and burnishing the overall reputation of a country's productive capacity. Finally, national leaders are alert to the putative value of media as an instrument of soft power, potentially enabling them exercise political and cultural leadership on a wide range of issues, both at home and abroad.

As they consider their options, media policy makers are anxiously looking over their shoulders to compare and measure their efforts in relation to distant others. They do so for both political and competitive reasons, and because traditional mechanisms of national media policy have proven largely ineffective in an era of transnational cultural flows. Regulators are therefore searching for fresh ideas that can help them navigate turbulent and uncharted waters. This essay provides a framework for understanding the twenty-first century dynamics of the global media economy as well as the dramatically novel conditions under which media policies are made. It has four central objectives: (1) explain the fundamental shift in media regulation engendered by neo-liberal globalization, briefly tracing historical milestones and analyzing the ways in which policy objectives and processes have been radically transformed over the last three decades; (2) describe the operations of transnational commercial media enterprises and show how their practices and protocols have affected media institutions at the local, national, and regional levels; (3) identify issues that have risen to the forefront of media policy deliberations with respect to cultural expression and creative labor; and (4) elaborate an alternative policy perspective based on the principle of stewardship, a concept that has in other contexts been used effectively to manage tensions between personal, public, state, and commercial interests. 


\section{NATIONAL POLICY, GLOBAL CONCERNS}

Much of the English-language scholarship on media regulation focuses on national policymaking, especially in the United States, United Kingdom, and Australia. American broadcasting throughout its history has been driven by commercial imperatives that are tempered by public interest policies. Overall, the national public is ostensibly paramount, but commercial considerations have prevailed, initially under the guise of corporate liberalism and more recently under tenets of neo-liberalism (Horwitz, 1989; Streeter, 1996; Pickard, 2014). The main alternative to American commercialism is public service media, as pioneered by the British Broadcasting System which provided a model that has been emulated in many countries over the past century (Scannell and David, 1991; Garnham, 2000; Hilmes 2011). The BBC was initially established to promote the British electronics industry, mediate class tensions, cultivate imperial loyalties, and fend off cultural competition from American music and motion picture imports. With the exception of Hilmes, much of what has been written about the history of UK and US media regulation focuses almost exclusively on national policy processes.

As for analysis of contemporary media policy, much of the US scholarship pivots around issues of commercialism and corporate conglomeration, but, interestingly, it pays little attention to globalization's impact on media institutions and practices. (Wu, 2010; Holt, 2011; Crawford, 2012; McChesney, 2013). British scholarship exhibits a similar national bias (Lunt and Livingstone, 2012), but Robert Hewison's Cultural Capital (Verso, 2014) shows how global forces have since the 1990s prompted British cultural institutions to veer towards commercialism. Despite the fact that global conglomerates have grown increasingly influential, national policy pays scant attention the broader implications of this transformation.

So far as international media scholarship is concerned, it too has exhibited a similar bias, making comparisons between national media systems (Siebert, et.al., 1956; Katz and Wedell, 1977; Hallin and Mancini, 2004) or analyzing media flows and influences between countries. Media imperialism researchers have, however, attempted introduce a broader spectrum of relations; most prominently, Thomas Guback (1969) and Herbert Schiller (1969) published contemporaneous critiques of US media hegemony. From a Latin American perspective, Armand Mattelart (Siegelaub and Mattelart, 1979) situated media imperialism within the context of class struggle. This scholarship research coalesced into a campaign for a New World Information and Communication Order (NWICO), which engendered a UNESCO report (International [MacBride] Commission, 1980) that thoroughly criticized the hegemony of Anglo-American media (Tunstall, 
1977) and called for reforms that would shore up national media regulation and sovereignty. The campaign drew broad-based support in the United Nations before being quashed by the US and UK delegations at the behest of the Reagan and Thatcher governments. Overall, media imperialism scholarship expanded the policy frame significantly, but the nation-state nevertheless remained the primary point of reference, analysis, and intervention.

The Anglo-American counter-attack on the NWICO initiative was accompanied by a decade of structural adjustment instigated by the Reagan and Thatcher governments, engendering a wave of deregulation as well as the privatization of publicly owned national institutions in such areas as finance, healthcare, transportation, and media. This neo-liberal agenda also included numerous rounds of international negotiations aimed at reducing trade barriers and tariffs, even in the realm of culture, an area of personal concern for the former actor-turned president, Ronald Reagan, who approvingly noted that entertainment had risen to become the second largest export industry of the United States. Consequently, feature films and television shows began to flow more freely across borders and corporate conglomerates began to extend their operations around the world. Miller et al. (2008), offer a trenchant political economy of these transformations, focusing especially on late twentieth century media conglomerates. Not only were the structural conditions of media transformed but so too were the institutional practices of distributors and producers (Bielby and Harrington, 2008; Mirrlees, 2013) as well as the quotidian behaviors and relationships among audiences (Rantanen, 2004).

These sweeping changes at the global level filtered down into the mundane mechanics of national and local policy making, unleashing fierce competition to attract global capital (Harvey, 1989; Castells, 1992; Sassen, 2001) and to compete for creative talent in order to nourish the service and information industries that have become exceptionally prosperous sectors of the global economy (Florida, 2005). This growing attention to the creative economy was magnified by the migration of manufacturing jobs from mature industrialized countries like the United Kingdom to low-wage, non-union labor in places like southern China. A contingent of policy scholars contended that that de-industrialization could best be addressed by enhancing human capital in industries with high value-added products (Porter, 1990; Howkins, 2002). Policymakers around the world now use

1. See for example, <http:// www.thecreativeindustries. co.uk/uk-creative-overview/ why-the-uk> and <http:// www.artswisconsin.org/ resources/creative-economyresource-center/>. this rationale to justify subsidies, infrastructural investments, and training programs in media, computer, and design industries ${ }^{1}$. Michael Keane (2013) shows, for example, that Chinese policy makers have attempted to use these strategies to make China a more prominent cultural producer and exporter. Although controversial, many scholars and policy makers have nevertheless embraced 
such policies, realizing that a failure to take action could doom the prospects of local media institutions and further strengthen the grip of media capitals like Hollywood and Mumbai. Scholars are nevertheless carefully observant of the challenges and potential pitfalls of such policy prescriptions (Goldsmith et al, 2010; Baltruschat, 2010; Flew, 2011; Cunningham, 2013).

The following analysis is situated at the crossroads of these literatures on media regulation and globalization. The transnational corporate conglomeration of media has relentlessly eroded national cultural sovereignty, altering the terms under which media policies can be conceived and executed. Where once policy makers could confidently craft regulations that shaped the terms of cultural production and circulation within their borders, today they are anxious onlookers as the transnational flow of media content relentlessly escalates. Audiences now pick and choose from a cornucopia of movies, television shows, and videos, most of it delivered by digital technologies that can circumvent even the tightest restrictions. Although the popularity of local and national content endures, it does so under conditions that are shaped by global market forces and professional practices. Media regulation, which was once a national prerogative, now takes place in a context significantly influenced by forces from afar. Yet most of what is written about contemporary policy making continues to focus on national contexts and concerns. Regulators must expand their frame of reference and reassess the constitutional principles ( $\mathrm{Wu}, 2010)$ that guide their deliberations. Policy makers cannot simply tinker with techniques from years gone by, they must rethink the fundamental assumptions that guide them, focusing less on public interest or public service and turning their attention instead to the concept of media stewardship.

\section{THE HISTORICAL ORIGINS OF NATIONAL MEDIA POLICY}

The roots of modern media policy reach back to the book publishing revolution of the fifteenth century that dramatically expanded the availability and geographic circulation of images and ideas. Despite the fact that publishing during that era took place under the auspices of influential patrons, it nevertheless proved contentious since the growing profusion of titles encouraged an expansion of literacy and public deliberation. Authoritarian political and religious leaders responded by licensing publishers, censoring content, and limiting the importation of foreign texts. Both producers and consumers chafed at these constraints, twinning the struggle for freedom of expression to Enlightenment principles of science and philosophy. Eventually, book and newspaper publishing became crucial components of republican political movements in the Americas and Europe during the eighteenth and nineteenth centuries, situating media 
policy as a foundational concern of modern nation-states. As these new states emerged, their fortunes were furthermore affected by innovations in electronic communication that facilitated the establishment of national railroad systems, industrial infrastructures, commercial markets, and popular mass media. The arrival of film and broadcasting in the twentieth century expanded the horizons of public life even further, reaching out to large and diverse audiences regardless of income, education, gender, or ethnicity.

Policy principles sought to grapple with the purpose and performance media in the midst of these tumultuous social transformations. The conceptual foundations that guided the development of national media systems were founded on such principles as public service (United Kingdom), public interest (United States), and propaganda (Soviet Union). In the Global South, colonial media regulations prevailed in most places, premised on British, French, or German ambitions to integrate and regulate far-flung imperial institutions and populations. In Latin America, national elites embraced US commercial policies perpetuating relations of dependency while also pursuing development policies with uneven results (Brazil, Mexico). Similar dynamics emerged in the postcolonial societies of Africa, Asia, and the Middle East where residual ties to the European powers manifested themselves in media policies that foregrounded socio-economic development (Ghana, India) and respectful attention to ruling regimes, what became known as protocol media (Saudi Arabia). Whether they media institutions were organized around public interest, public service, propaganda, colonial, dependent, development, or protocol principles, they were all intimately tied to national regimes of governance and envisioned as instruments of modernization and popular mobilization. Similarly, international media policy has been premised on state supremacy, envisioning the world as a collection of nation-states that are in principle entitled to media sovereignty.

\section{GLOBALIZATION AND CREATIVE ECONOMIES}

During the 1980s and 1990s, Western corporations and financial institutions advocated policy reforms aimed at reducing trade barriers and more thoroughly integrating countries into a global capitalist economy. These objectives depended on the improvement of communication technologies, especially satellite and transoceanic cables that served as conduits for digital imagery and information. Within less than a decade it became possible to trade securities on the far side of the world and to integrate transnational manufacturing operations for automobiles or electronics. Yet perhaps the most riveting metaphor of transformation during this era was cultural rather than financial, for satellite television 
seemed to embody both the shifting scale of social relations and the quotidian experience of a nascent global society.

Newspapers, magazines, and other media carried colorful portrayals of MTV viewers in remote Southeast Asian villages and Saudi households tuning into provocative variety shows from Beirut. Many news reports featured breathless accounts of villagers in the rugged Himalayas or in the far reaches of the Amazon marveling at shimmering alien images from afar. Exempt from national broadcasting regulations, satellite signals and smuggled video recordings encouraged audiences to imagine distant worlds and reassess their local circumstances. Many critics during this period presumed that an acceleration of cultural flows were fueling campaigns for social change, leading to demonstrations at Tiananmen, the fall of the Berlin Wall, and the demise of authoritarian regimes in countries such as Taiwan and South Korea.

Satellite TV was furthermore entwined with the ambitions of transnational media conglomerates, the new hydra-headed configurations of corporate culture that began to gobble up competitors and relentlessly roll out services around the world. HBO, MTV, and Disney became ever more available via satellite, a technology that could deliver signals across vast continents without requiring the construction of terrestrial transmission towers, thereby annihilating spatial barriers that previously seemed intractable. The technology promised expansive and instantaneous diffusion, and furthermore seemed immune to government regulation due to the fact that transmissions came from outer space and reception technology was radically decentralized. It offered a dazzling window of opportunity for advertisers who imagined themselves hawking their products to the far ends of the earth.

Therefore, investment in communication technologies escalated dramatically during the 1990s, inflating into a bubble that burst at the turn of the century due to excessive expansion of cable and satellite capacity. One of the unintended consequences of this collapse was the sudden availability of new media production and distribution technologies at very low prices. As a result, the number of media producers, distributors, and consumers grew dramatically during the last two decades of the twentieth century, first in Europe and then in Asia, with China and India adding almost two billion television viewers in a very short time.

Yet even though the arrival of new satellite services seemed in many parts of the world to be a powerful external force, companies nevertheless learned over time that they would have to compete on an ongoing basis against an array of global, national, and local services, each of them shifting their strategies in response to dynamic market forces and cultural trends. Rather than 
simply imposing their will, transnational media conglomerates had to make adjustments as other global competitors entered the market and as national and local broadcasters appropriated global styles and strategies, creating their own hybrid services. Global conglomerates therefore localized their offerings while local companies globalized theirs, some of the latter launching satellite ventures of their own. Even though a transnational strategy was the most common rationale for launching any satellite service, most companies discovered that terrestrial conditions nevertheless exerted a strong gravitational force, inexorably tugging global services back to earth where they had to compete under conditions that are not necessarily of their own making. So although powerful global corporations initiated this media revolution, local, national, and regional media have influenced it in significant and often unexpected ways. In fact, even though transnational products are more available than ever before, audiences continue to spend much of their time with content that stimulates cultural affinities based on language, ethnicity, or colonial heritage. To the extent that viewers venture beyond local or national fare, they survey a menu of alternatives that is far more diverse than Hollywood ever imagined. Arab audiences, for example, are enamored of Turkish dramas, which have been strongly influenced by Latin American telenovelas. And Nigerians adore Indian musicals and Chinese martial arts movies, which have in turn inspired Nigerian videofilms that are popular across Africa and throughout the African diaspora.

Consequently, cities such as Lagos, Miami, and Mumbai have emerged as commercial media capitals that are increasingly competitive with Hollywood's transnational cultural influence. This condensation of power and influence in particular cities is premised on interactions between institutions and actors that show greater regard for audience preferences than government priorities. Policy makers are therefore confronted by a distinctive new set of challenges as they try to cultivate homegrown creative talent and position them favorably within global networks. Some governments play a passive role, occasionally lending a hand to media entrepreneurs pursuing a relentlessly commercial agenda that is keenly attuned to popular tastes. Others take an alternative route that positions government institutions in a leadership role, actively cultivating resources that aim to promote their national (and often government-owned) media with domestic audiences and to angle for cultural influence abroad. Cities that benefit from such calculated state policies-such as Beijing, Seoul, and Dubai-could therefore be considered official media capitals as opposed to their commercial counterparts. Regardless of the approach, certain cities have emerged as centers of an growing transnational media economy. 


\section{CULTURAL CONCERNS}

Yet only a handful of cosmopolitan centers can realistically aspire to become a media capital. What about other locales in small nations and poor states that are subject to cultural influences from wealthier counterparts? What are the prospects for creative endeavor in Benin, Nigeria's neighbor, or in Nepal, nestled between India and China? Similarly, what should be done for subnational populations in places like Oaxaca, who live in provinces and towns that are culturally distinct but nevertheless susceptible to influences from distant metropolitan centers, such as Mexico City? And what might be done for metropolitan media that vie with nearby neighbors for cultural and commercial prominence, as is the case in the Pearl River Delta where Hong Kong film and TV prevail over competitors from Guangzhou and Shenzhen? These spatial dynamics are not entirely new. In fact, they have been an enduring feature of the modern era ever since the development of print capitalism. Media and markets have long conspired to privilege some places over others and because of these inequities, modern governments have persistently sought to assert their cultural authority and political sovereignty. So important are these principles that governments have repeatedly intervened in the realm of popular communication so that political capital sometimes counts as much if not more than economic or creative capital. In extreme cases, media have at times become instruments of the state or of an autocratic elite, but at their very best public media institutions and enlightened media policies have provided the means by which common legacies have been maintained, policies debated, and futures imagined.

The trend toward media globalization has, however, undermined many of the conventional tools of policy makers. Traditionally, regulators intervened most effectively in the realms of distribution and consumption by limiting imports and technological access, or by censoring content before it made its way into circulation. Nowadays these tools have limited value and in fact may be counterproductive due to the availability of technologies that can circumvent official restrictions. The Chinese government, for example, limits the number of Hollywood movies imported each year, but this has little effect on the actual consumption of foreign films in China, since they are widely available through black and gray market distribution channels. Government sanctions not only fail to circumscribe personal consumption of foreign films, but they paradoxically have a negative impact on Chinese film and TV, since they drive audiences out of the officially-sanctioned media economy and foster resentment and distrust of government institutions.

Keeping citizens engaged with indigenous media requires that states not only acknowledge audience preferences but also their personal capacity to evade 
official constraints. Given these considerations, many governments have shifted their attention to the supply side of the policy equation. Instead of trying to restrict or manage consumption, they are looking for ways to nurture local, national, and regional media that offer distinctive and popular content that foreign enterprises are unlikely to provide. Many governments have therefore turned to the literature on creative economies, which seem to offer both a tonic for cultural sovereignty and a stimulus for the broader economy. But as they have done so, policy makers have unexpectedly unleashed a transnational scramble for media subsidies and resources that have an adverse effect on the lives of media talent, craft, and service labor.

\section{A CRISIS FOR CREATIVE LABOR}

It is remarkable and perhaps ironic that Hollywood is no longer the default setting for major feature films and television productions. In fact, Louisiana now hosts more Hollywood projects than any other location in the world. Although California remains one of the top five production centers by volume, it faces stiff competition from Canada, the United Kingdom, and the state of Georgia. Studio bosses and producers have made it clear that they intend to keep scouring the globe for lower labor rates and less regulated production sites. Right to work states are especially attractive, as are overseas locations where unions have little or no clout. In many places, governments offer tax breaks and subsidies as further inducements. Consequently, producers have grown ever more fleet-footed, playing one place off against another in a never-ending quest to secure the most favorable conditions for their bottom lines. Motion picture producers feel squeezed by corporate financial imperatives to contain costs, especially labor costs. Workdays are growing longer, productivity pressures more intense, and creative autonomy is diminishing. Overall, this has put severe financial, physical, and emotional strain on workers and their families and further threatens the many independent businesses that service the major producers.

What is perhaps most remarkable about these precarious labor conditions is that the pattern repeats itself in many parts of the world. In October 2008, the Federation of Western India Cine Employees, an alliance of 22 unions representing 147,00o below-the-line workers ranging from dancers and extras to editors and carpenters, called a citywide strike in Mumbai, the entertainment capital of South Asia. At the time, the average filmworker was making $\$ 9.75$ a day and the average television employee a little more than $\$ 8$ a day. In addition to wages, the strike raised concerns about long workdays that in some cases involved 30-hour shifts. On-the-job safety and meal breaks were other 
points of contention. Moreover, union leaders expressed deeper concerns about Bollywood producers hiring non-union workers and relocating productions outside of Mumbai, especially to overseas locations like Scotland and Australia. They also criticized a system of subcontracting that helps producers circumvent union agreements.

In his book, Nice Work If You Can Get It (2010), Andrew Ross argues that workers all over the world face similar pressures, from the low-end manufacturing sector in developing nations to white-collar workers in major cities. Ross contends that talent and training no longer guarantee access to a secure and meaningful job. Even though film and television workers are commonly characterized as highly trained industrial elites, they share many of the concerns that Ross identifies, concerns that have been fueled by the growth of media conglomerates and the globalization of production. Talent and creativity, the most ineffable drivers of modern media, are being seriously compromised by the enterprises and institutions that benefit most from their labor. Although policy makers in many parts of the world have figured out how to strengthen their technological and institutional infrastructures, the most vexing policies issues invariably revolve around talent. How does one recognize, nurture, reward, and retain talent? Toward what ends? And for whom?

\section{STEWARDSHIP}

As the foregoing factors suggest, governments should focus on the supply side of the policy equation, looking for ways to nurture local and national media that offer distinctive cultural services, ones that foreign enterprises are unlikely to provide. Bolstered by such support, some national and local media enterprises may be able to compete with global counterparts, however, most will never be able to do so, nor should they. Policymaking should instead jettison its preoccupation with competing in the global creative economy and instead emphasize the disparate public purposes of modern media, which like parks, libraries, and childcare centers are resources that make places worth living. The analogy to public parks is especially intriguing, since it points to traditions of policymaking in the field of resource management.

Throughout the twentieth century, policy makers in many countries have wrestled with competing claims on natural resources, forcing them to come up with principles that strike a balance between seemingly incommensurable interests and ambitions. Commercial enterprises, private stakeholders, and political elites certainly command the attention of environmental planners, but so too do other constituencies, such that urban parks make space for multiple uses, arboretums cultivate plant diversity, community gardens expand 
food sources, and farmers' markets support local agriculture. Each of these spaces is subsidized and sequestered from conventional market forces and even though they may contribute to the overall commercial value of a place, they are primarily justified by their ability to offer opportunities the market will not. This ethic extends outside the cities where national forests provide recreational activities, national parks offer public access to the diverse wonders of the natural environment, and wilderness areas shelter species that cannot on their own withstand the pressures of human population growth and commercial avarice. Wilderness areas are particularly compelling examples of stewardship. For public policy supports them knowing that the vast majority of citizens will never venture inside and that access will only be granted to those that are willing to enter on conditions that are specific to the local ecosystem.

Accordingly, stewardship principles have several virtues when applied to media policy, especially in societies outside the world's major production centers. Unlike government media regulations of the past, stewardship principles suggest that public media should not be configured as appendages of the state nor should they promote (or defend) a singular vision of national culture. Instead sustainable media institutions should have multiple objectives and institutional configurations. They might on the one hand blend public and private resources, while on the other help to sustain micro communities or oppositional constituencies that have absolutely no commercial value. Public media should be characterized - like any healthy ecosystem - by tension and antagonism, as well as interdependence and symbiosis. They should be protean institutions that change over time but nevertheless are guided by a long-term ambition to foster a rich assortment of cultural resources at a variety of geographic scales.

Confronted by the spatially expansive and intrusive operations of global media conglomerates, government officials have too often confused cultural concerns with economic and political objectives. Media policy makers should instead measure success as much by the appreciative crowds that gather as by those that don't, knowing that a diversity of uses and pleasures is as important as the cold accountability of ticket sales, attendance records, and export statistics. They should jettison principles of public service, public interest, development, and creative economy, turning their attention instead to a multiplicity of media needs and uses at a variety of cultural and geographic scales. Media stewardship will no doubt be controversial, but if its environmental counterpart is any guide, it can win the support of citizens so long as it unambiguously advances the vision that everyone benefits from a diversity of opportunities that markets alone are unlikely to provide. $\mathbf{M}$ 


\section{REFERENCES}

BALTRUSCHAT, Doris. Global Media Ecologies: Networked Production in Film and Television. New York: Routledge, 2010.

BIELBY, Denise and HARRINGTON, C. Global TV: Exporting Television and Culture in the World Market. New York: NYU Press, 2008.

CASTELLS, Manuel. The Informational City: Economic Restructuring and Urban Development. Reprint edition. Wiley-Blackwell, 1992.

CRAWFORD, Susan. Captive Audience: The Telecom Industry and Monopoly Power in the New Gilded Age. New Haven Conn.: Yale University Press, 2012.

CUNNINGHAM, Stuart. Hidden Innovation: Policy, Industry and the Creative Sector. Lanham: Lexington Books, 2013.

CURTIN, Michael. Media Capital Towards the Study of Spatial Flows. International Journal of Cultural Studies 6, no. 2, p. 202-228, Jun. 1, 2003. DOI: http://dx.doi. org/10.1177/13678779030062004

Global Media Capital and Local Media Policy. In: WASKO, Janet; MURDOCK, Graham, and SOUSA, Helena (eds.). The Handbook of Political Economy of Communications, Wiley-Blackwell, 2011. p. 541-57.

FLEW, Terry. The Creative Industries: Culture and Policy. Los Angeles, Calif: SAGE Publications Ltd, 2011.

FLORIDA, Richard L. Cities and the Creative Class. New York: Routledge, 2005.

GARNHAM, Nicholas. Emancipation, the Media, and Modernity: Arguments about the Media and Social Theory. Oxford; New York: Oxford University Press, 2000.

GOLDSMITH, Ben; O’REGAN, Tom, and WARD, Susan. Local Hollywood: Global Film Production and the Gold Coast. St Lucia, Qld: University of Queensland Press, 2010.

GUBACK, Thomas H. The International Film Industry; Western Europe and America since 1945. Bloomington: Indiana University Press, 1969.

HALLIN, Daniel C. and MANCINI, Paolo. Comparing Media Systems: Three Models of Media and Politics. Cambridge, UK ; New York: Cambridge University Press, 2004.

HARVEY, David. The Condition of Postmodernity: An Enquiry into the Origins of Cultural Change. New York: Blackwell, 1989.

HEWISON, Robert. Cultural Capital: The Rise and Fall of Creative Britain. London ; New York: Verso, 2014.

HILMES, Michele. Network Nations: A Transnational History of British and American Broadcasting. New York: Routledge, 2011.

HOLT, Jennifer. Empires of Entertainment: Media Industries and the Politics of Deregulation, 1980-1996. New Brunswick: Rutgers University Press, 2011. 
HORWITZ, Robert Britt. The Irony of Regulatory Reform: The Deregulation of American Telecommunications. New York: Oxford University Press, 1989.

HOWKINS, John. The Creative Economy: How People Make Money from Ideas. London: Penguin, 2002.

INTERNATIONAL Commission for the Study of Communication Problems [MacBride Commission]. Many Voices, One World: Communication and Society, Today and Tomorrow: Towards a New More Just and More Efficient World Information and Communication Order. New York: Unipub, 1980.

KATZ, Elihu and WEDELL, E. G. Broadcasting in the Third World: Promise and Performance. Cambridge: Harvard University Press, 1977.

KEANE, Michael. Creative Industries in China: Art, Design and Media. Cambridge, UK; Malden, MA: Polity Press, 2013.

LUNT, Peter K. and LIVINGSTONE, Sonia M. Media Regulation: Governance and the Interest of Citizens and Consumers. Los Angeles: Sage, 2012.

McCHESNEY, Robert W. Digital Disconnect: How Capitalism Is Turning the Internet Against Democracy. New York: New Press, 2013.

MILLER, Toby et al. Global Hollywood: No. 2. $2^{\text {a }}$ ed. London: British Film Institute, 2008.

MIRRLEES, Tanner. Global Entertainment Media: Between Cultural Imperialism and Cultural Globalization. New York: Routledge, 2013.

PICKARD, Victor W. America's Battle for Media Democracy: The Triumph of Corporate Libertarianism and the Future of Media Reform. Cambridge University Press, 2014.

PORTER, Michael E. The Competitive Advantage of Nations. New York: Free Press, 1990.

RANTANEN, Terhi. The Media and Globalization. London: SAGE Publications Ltd, 2004.

ROSS, Andrew. Nice Work If You Can Get It: Life and Labor in Precarious Times. New York: New York University Press, 2009.

SASSEN, Saskia. The Global City: New York, London, Tokyo. Princeton, N.J: Princeton University Press, 2001.

SCANNELL, Paddy and CARDIFF, David. A Social History of British Broadcasting. Oxford, UK; Cambridge, Mass., USA: Blackwell, 1991.

SCHILLER, Herbert I. Mass Communications and American Empire. New York: A. M. Kelley, 1969.

SIEBERT, Fred S. et al. Four Theories of the Press: The Authoritarian, Libertarian, Social Responsibility, and Soviet Communist Concepts of What the Press Should Be and Do. Urbana: University of Illinois Press, 1956.

SIEGELAUB, Seth and MATTELART, Armand (eds.). Communication and Class Struggle, Vol. 1: Capitalism, Imperialism. New York: Bagnolet, France: International General/Intl Mass Media Research Cen, 1979. 
STREETER, Thomas. Selling the Air: A Critique of the Policy of Commercial Broadcasting in the United States. Chicago: University of Chicago Press, 1996.

TUNSTALL, Jeremy. The Media Are American. New York: Columbia University Press, 1977.

WU, Tim. The Master Switch: The Rise and Fall of Information Empires. New York: Alfred A. Knopf, 2010.

This text was received at 30 March, 2015 and accepted at 25 April, 2015. 